\title{
Challenging career models in higher education: the influence of internal career scripts and the rise of the "concertina" career
}

\author{
Celia Whitchurch $^{1}$ (D) $\cdot$ William Locke $^{2}$ (D) $\cdot$ Giulio Marini ${ }^{3}$ (D)
}

Accepted: 19 May 2021 / Published online: 22 June 2021

(C) The Author(s) 2021

\begin{abstract}
The paper develops the metaphorical concept of the "concertina" career to describe ways in which academic staff, across a diversifying workforce, modulate their interactions with institutional career frameworks, which tend to be unilinear and to be characterised by detailed progression criteria and milestones. In doing this, they are guided by Internal career scripts, providing an additional dimension to the dichotomy of boundaried and boundaryless careers found in the literature. Drawing on a longitudinal study between 2017 and 2020, of forty-nine mid-career academic staff across eight UK universities, consideration is given to individuals' spatial movements, for instance, between academic activities, and professional and personal commitments; and the manipulation of timescales to accelerate or decelerate career progress in relation to opportunities and constraints. The study shows ways in which the spatial parameters of a career are being stretched in order to accommodate new forms of academic work supplementing disciplinary activity, such as online learning, employability initiatives and public engagement, as well as worklife considerations. In addition, individuals are adapting timescales to accommodate professional activities such as health practice or community outreach, as well as personal commitments such as caring responsibilities. Thus, in the concertina career, individuals expand and contract activity, as well as extending and compressing timescales. As a result, it is concluded that institutional career models do not entirely reflect the reality of career-making by individuals, which is likely to involve detours (therefore a spatial dimension) and a disruption of assumed timelines (therefore a temporal dimension).
\end{abstract}

Keywords Academic career-making $\cdot$ Academic career pathways

Celia Whitchurch

c.whitchurch@ucl.ac.uk

Extended author information available on the last page of the article 


\section{Introduction}

Academic career pathways in the UK have, in recent years, been characterised by increasingly detailed progression criteria and milestones. Such descriptors assume that academic careers are "a linear and, to large extent, a predictable process..." (Kwiek \& Antonowicz, 2015: 58). Yet, behind what might be seen as greater clarity in defining the components of a career lies a range of interpretations and responses by individuals. These two intersecting dynamics hint at the tension between institutional rubrics and the actual process of career-making in higher education institutions. The impact of this tension on the way that individuals enact their careers is explored in this paper, demonstrating that institutional career models tend to disguise the reality that the progression of an individual may involve detours (therefore a spatial dimension) and a disruption of assumed timelines (therefore a temporal dimension). Furthermore, the study that is the subject of the paper included a re-interviewing process, two years after the first set of interviews, which created a longitudinal dimension. The findings suggest that the situation is more nuanced than as understood in earlier applications of career theory to higher education.

The paper develops the metaphorical concept of the "concertina" career to demonstrate ways in which, in the same way as the musical instrument expands and contracts in musicmaking, the process of career-making expands and contracts in relation to the different spaces that individuals find themselves in, over extended time periods. Thus, the direction and tempo of a career may not follow the linear pathway assumed by institutional career templates. In developing this concept, the paper draws on the notion of career scripts to show how the career paths of individuals are informed by personal strengths, interests and commitments, as well as by formal career structures. Hence, scripts are internally, as well as externally, generated.

Associated with these phenomena is the fact that the academic workforce is diversifying. Twenty of the forty-nine interviewees in the study on which this paper is based had come into higher education from a different sector, including, for example, the UK National Health Service (NHS), humanitarian work, journalism/media, the probation service and career guidance. This in turn introduces relationships between academic activity and a range of settings and agencies. Diversification is also taking place within higher education, with individuals developing a focus on specific areas around teaching and learning, such as the student experience, online learning and community engagement.

The paper begins by reviewing ideas about academic careers in the context of a range of theoretical frameworks and of the literature. It goes on to describe the methods used in conducting the study, followed by some of its findings and our analysis. These include the emergence of career scripts and ways in which these guide individuals during the process of career-making, as they negotiate space and time to develop concertina-like careers.

\section{Theoretical framing}

\section{Career systems}

Academic careers in the UK have tended to be more fluid than has been the case in some parts of continental Europe and the USA. In these countries, formal tenure track models have operated, with strict qualification requirements for a tenured post (Pietilä, 2017). Other countries have four-stage models of doctorate, post-doctoral work, independent researcher/ 
lecturer and professor (League of European Research Universities, 2014). The latter model broadly corresponds to practice in the UK, where academic tenure was abolished for new or promoted posts in 1988. Individuals appointed to a lectureship would have an expectation of proceeding to a senior lectureship (in some institutions titled associate professor), and possibly a professorship, in due course. As a first stage in their careers, those individuals who progress directly from doctoral work are likely to be appointed on a fixed term research or teachingonly appointment, although those having research appointments may undertake some teaching, and those having teaching appointments may undertake some unfunded research. In both cases, the aim is usually to obtain experience with a view to progressing to an open-ended, as opposed to fixed term, teaching and research appointment (Locke et al., 2016). Within these arrangements, individuals are required to distinguish themselves by meeting progression criteria in the same way as they would in tenure track systems.

\section{Career scripts}

The tension between institutional structures and the aspirations of individuals has framed career theory more generally, whereby organisations such as universities are seen as providing career structures, as a "road map" in the form of entry and progression points; and individuals are seen as having agency to manage the way that they interact with this "road map", according to their interpretation of institutional "career scripts" (Dany et al., 2011; Duberley et al., 2006; Garbe \& Duberley, 2019). These scripts outline different ways of making a career, for example, via a focus on research, teaching and/or academic management, the balance of which may shift over time (Baruch, 2004). On the one hand, UK institutions have been influenced by government policy, linking individual performance review to the contribution of individuals to national Research Excellence and (in England) Teaching Excellence Frameworks. On the other hand, institutional career scripts have expanded to encompass a range of activity, including, for example, employability agendas and public engagement. This has led to "a trend towards a more individual management of academic careers replacing the more collective treatment of a supposedly homogeneous group" (Musselin, 2013: 29). Nevertheless, institutional career scripts represent objective markers of individual positioning, as opposed to the Internal scripts of individuals, the latter reflecting drivers such as personal strengths and commitments.

\section{Boundaried and boundaryless careers}

In the application of career theory to higher education, approaches to career-making have tended to be broadly characterised in one of two ways: firstly, positional careers in which individuals rely on institutional structures such as promotion criteria and career tracks, within one or more institutions, and are therefore "boundaried" (Dowd \& Kaplan, 2005); and secondly, non-positional careers that are "boundaryless" (Arthur \& Rousseau, 1996; Dowd \& Kaplan, 2005) or "protean" (Ortlieb \& Weiss, 2018), incorporating activity outwith institutional parameters. We aimed to move beyond this dichotomy, accommodating the fact that some individuals enter higher education later in their careers, and some move in and out. Moreover, we acknowledge that the concept of the discipline is being stretched by, for example, professional practice. Disciplinary boundaries are also weakening as real-world problems demand interdisciplinary solutions, including knowledge from the sciences but also from the human disciplines. Thus, even those individuals who want to advance in what might 
be regarded as relatively boundaried disciplines, with less obvious practical applications, are encouraged to think about how they could scale up their activity in ways that are relevant to real-world purposes.

\section{Identity}

A gloss on the "boundaried/boundaryless" view of careers is offered by theories of identity focusing on structure and agency and the interaction between the individual and the structures in which they find themselves (Delanty, 2008; Henkel, 2000; Leisyte \& Hosch-Dayican, 2016; Ylijoki, 2013). At a more detailed level, the construction of identity has been seen as a cycle of interactions whereby the individual moves from passive to active mode, in dialogue with him or herself, and with the social structures that he or she occupies (Archer, 2000). In Archer's terms, the "me", as primary agent, might be said to represent the initial position of an individual who, on appointment, accepts a career pathway represented in the job description that forms part of their contract. The passive enactment of a career involves reproduction of practice by adhering to established institutional progression criteria and pathways, in Archer's terminology, the condition of "morphostasis". However, in practice, career-making is likely to involve "assuming a [series of] role $[s]$ and personifying $[$ them $]$, by investing oneself in $[$ them $]$ and executing [them] in a singular manner" (Archer, 2000: 11-authors' italics). The individual's interpretation of a role, or series of roles, distinguishes them from other individuals with similar contracts. The diversification of the workforce has meant that in practice there are increasing numbers of people who are likely to offer "unscripted performances" (Archer, 2000: 7). Through interactions with others, individual approaches to career-making, driven by what we have termed Internal, rather than Institutional, scripts, may gather collective momentum, and ultimately result in the transformation of practice, described as "morphogenesis".

\section{Literature}

The literature on academic careers can be broadly categorised as demonstrating:

- Broad-brush employment trends (fixed term, open-ended, part-time, casual) represented by large data sets collected via survey instruments (Baruch, 2013; Galaz-Fontes et al., 2016; Kwiek, 2019; Machado-Taylor et al., 2017; Siekkinen et al., 2019).

- The responses of individuals, particularly early career staff, to less certain conditions and the increasing pressures of academic life (Archer, 2008; Gornall et al., 2014; Jones et al., 2020; Marini, 2019; McAlpine, 2010; McAlpine \& Amundsen, 2018; Ortlieb \& Weiss, 2018; Rosewell \& Ashwin, 2019; Ylijoki and Henriksson, 2017; Ylijoki \& Ursin, 2013; Yudkevich et al., 2015).

- The impact of career structures at national levels, including the use of tenure track arrangements and market mechanisms such as the UK Research Excellence Framework and the knowledge economy (Coates \& Goedegebuure, 2010; Enders \& de Weert, 2009; Musselin, 2013; Pietilä, 2017; Pietilä \& Pinheiro, 2020; Strike \& Taylor, 2009; Watermeyer \& Tomlinson, 2021).

- Career typologies focusing on the individual, including the concept of the kaleidoscope career (Mainiero \& Sullivan, 2006), suggesting that the individual has multiple considerations when making decisions about their career (Baruch, 2013; Sullivan \& Baruch, 2009), 
which can involve "intersecting identities" (professional, personal and relational) (Pifer \& Baker, 2016: 192).

- The interaction between individuals and institutional structures, and the degree of agency that they are able to exercise, for example via "boundaried" and "boundaryless" approaches (Dany et al., 2011; Dowd \& Kaplan, 2005; Glaser \& Laudel, 2015; Kaulisch \& Enders, 2005; Ortlieb \& Weiss, 2018; Siekkinen et al., 2019; Whitchurch, 2018). It is apparent from this literature that whatever type of career framework academic staff work within, the way that individuals interact with institutional structures is a common theme that crosses national boundaries.

However, the literature tends not to account for ways in which individuals may play with, or even push the boundaries of formal career pathways, for instance, by being opportunistic, focusing for the time being on what needs to be done for the next promotion, negotiating a different balance of activity, or creatively interpreting what they find in human resource policies. Thus, there would appear to be a spectrum of approaches, from which individuals may develop a strategy that will serve them for a range of purposes that includes career advancement, but also the satisfaction of personal strengths and interests. To achieve a more nuanced picture of career-making, therefore, this paper develops the concept of Internal career scripts, modulating the dichotomy of boundaried and boundaryless careers.

\section{Method}

\section{Selection of case institutions and interviewees}

Eight case study institutions were selected on the basis of:

- National location (five English and one each from Scotland, Wales and Northern Ireland).

- Institutional type (three pre-1992 Russell Group (leading research-intensive universities); two pre-1992 non-Russell Group; two post-1992 universities (former polytechnics prior to the Further and Higher Education Act 1992); and one post-2004 university (former College prior to 2004, when the requirement that institutions gain research degree awarding powers before they could gain university status was dropped in England and Wales)).

- Disciplinary and staff profiles.

The aim was to achieve as broad and balanced a range of profiles as possible, across the geographical regions of the UK. In each of the case study institutions, the research team asked to interview eight individuals, to include the director of human resources; a pro-vice chancellor; one early and one mid-career academic member of staff; one individual with a teachingonly contract; one with a research-only contract; one with a learning support remit; and one with a traditional teaching and research remit. The focus of this paper is on 49 academic staff in the first round of interviews (Autumn 2017 to Spring 2018) not having senior management team roles, including 39 of these who agreed to be re-interviewed in the second round (Autumn 2019 to Spring 2020), as shown in Table 1.

Of the 10 people who were not re-interviewed, one had retired, and the others either did not respond to requests for an interview, declined, or said that they did not have time, despite 
Table 1 Employment category of academic staff interviewed in the first and second round of interviews

\begin{tabular}{lll}
\hline & $\begin{array}{l}\text { First round of } \\
\text { interviews (2017-2018) }\end{array}$ & $\begin{array}{l}\text { Second round of } \\
\text { interviews (2019-2020) }\end{array}$ \\
\hline Middle managers, e.g. heads of school and department & 9 & 8 \\
Teaching and research staff & 28 & 22 \\
Teaching-only staff & 2 & 2 \\
Research-only staff & 5 & 4 \\
Learning support staff & 5 & 3 \\
Totals & 49 & 39 \\
\hline
\end{tabular}

follow-up emails and phone calls. Of the 39 individuals re-interviewed, 15, i.e., just over one third, had been promoted, as shown in Table 2.

By the time of the second interviews, all but two of the respondents had established career positions. The two remaining were relatively settled in research roles which they felt could, if necessary, lead to a career outside higher education. Only one individual was part-time and, although six were formally appointed to teaching roles, they spoke of conducting unfunded or minimally funded research. The average age of the interviewees was 45; therefore the focus was on those in mid-career. Five had some kind of management role at dean or head of department level. They therefore spanned the later phases of a career (establishment (age 2645) and maintenance (age 46-65)), and were likely to have family responsibilities (Super, 1992). As noted by Zacher et al. (2019), those in mid- to later academic career stages have been neglected in the literature in comparison with those in the early stages of their careers.

\section{Interviews}

Two rounds of qualitative interviews were conducted, from Autumn 2017 to Spring 2018 and from Autumn 2019 to Spring 2020, to explore the perceptions of 49 academic members of staff about the progress of their careers over time. After the first round of interviews, individuals were initially mapped against existing broad-brush models of "boundaried" and "boundaryless" approaches to career-making. The former, labelled Mainstream, were driven by structural considerations and timelines, undertaking a cost-benefit analysis of activities

Table 2 Levels of seniority of academic staff interviewed in the first round of interviews; additional numbers in each category at the second round of interviews; and total numbers in each category at the second round of interviews

\begin{tabular}{llll}
\hline & $\begin{array}{l}\text { First round of } \\
\text { interviews 2017-2018 }\end{array}$ & $\begin{array}{l}\text { Additional numbers in each } \\
\text { category during second round } \\
\text { of interviews 2019-2020 as a } \\
\text { result of promotions }\end{array}$ & $\begin{array}{l}\text { Total numbers in each } \\
\text { category at second } \\
\text { round of interviews } \\
\text { 2019-2020 }\end{array}$ \\
\hline Professor (or equivalent) & 8 & 4 & 7 \\
Reader & 8 & 1 & 6 \\
Senior Lecturer & 11 & 6 & 12 \\
Lecturer & 16 & 3 & 10 \\
Senior research fellow & 0 & 1 & 1 \\
Research fellow & 6 & 0 & 3 \\
Totals & 49 & 15 & 39 \\
\hline
\end{tabular}

Note: Some of those in the professor category had titles such as head of learning and teaching or academic development 
deemed to be most valuable in the light of, for instance, progression criteria. The latter, labelled Portfolio, focused on a cumulative gathering of experience, both internal and external, and were not necessarily aligned to formal institutional pathways (Whitchurch et al., 2019).

It was also clear at this stage that not all individuals fell into these two broad categories. There was significant evidence of individuals making a positive decision to focus on a specific area of activity that they shaped and moulded for themselves, so as to achieve a positioning that they found comfortable and rewarding. In a sense this was their own, unique, space unlikely to be clearly represented in a job description or progression criteria. An additional, third, category labelled Niche, focusing on developing an area of personal interest and/or strength that is comfortable to the individual, which may nevertheless be developed for career purposes, was therefore created to describe individuals who adopted such an approach, either permanently or for the time being. This positioning, in which an individual effectively designs their local territory, and from that their career pathway, has not been well represented in the literature (Whitchurch et al., 2019).

This typology therefore represented dominant tendencies or dispositions, and individuals were placed in the category with which they appeared to have the strongest affiliation. The three categories were not mutually exclusive and, although individuals might show a disposition towards one category at any point in time, they might also hold on to the possibility of another. Across the original 49 interviewees, only seven displayed evidence of only one category; 21 displayed evidence of two; and 21 of three. However, this initial categorisation represented a snapshot in time, and therefore gave a static picture of what is, in reality, a process of career-making that evolves for each individual during the life course. Nor did it capture choices and decision-making that take place on an ongoing basis, or ways in which individuals are influenced in different degrees and at different periods by factors such as the perceived likelihood of achieving promotion, their relationships and networks, and considerations of personal strengths and interests. It therefore became evident that a longitudinal element was needed to demonstrate shifts between categories, two or more of which could be exemplified by an individual, not only at a single point in time, but also across the two year period.

\section{Findings}

\section{Shifts between career scripts}

The second round of interviews led to a shift from the one-dimensional typology described above (Whitchurch et al., 2019) to one that was more dynamic in capturing the momentum of a career. The concepts of Institutional and Internal career scripts, alongside Boundaryless scripts, were developed to understand the drivers behind the process of career-making, as described in Table 3.

The second round of interviews therefore provided an opportunity to review how the dominant career script of individuals might change over time. The categorisation of the dominant career scripts of individuals after both sets of interviews is summarised in Table 4.

A general shift can be detected from Boundaryless scripts to either Institutional or Internal scripts as the dominant script, over the two years. There would seem to be two pathologies represented: firstly, a more settled status, reflected in Institutional and Internal scripts, as people achieve the next career move or decide to focus on favoured activities; and secondly, a 
Table 3 Description of career scripts

\begin{tabular}{|c|c|c|c|}
\hline $\begin{array}{l}\text { Type of } \\
\text { career script }\end{array}$ & Characteristics & Associated activity & Goal(s)/outcomes \\
\hline Institutional & $\begin{array}{l}\text { Script closely aligned to formal } \\
\text { institutional promotion } \\
\text { criteria and timelines } \\
\text { Institutionally driven (e.g. } \\
\text { progression pathways, } \\
\text { promotion criteria) }\end{array}$ & $\begin{array}{l}\text { Pursuit of activities likely to lead to } \\
\text { promotion, whether in teaching, } \\
\text { research or other specified areas } \\
\text { Being strategic, even political with a } \\
\text { view to quantifiable career } \\
\text { outcomes and impact } \\
\text { Undertaking a cost-benefit analysis } \\
\text { of individual activities }\end{array}$ & $\begin{array}{l}\text { Timely promotion on } \\
\text { institutional career } \\
\text { progression } \\
\text { pathway(s) }\end{array}$ \\
\hline Boundaryless & $\begin{array}{l}\text { Script non-aligned with institu- } \\
\text { tional career pathways } \\
\text { Opportunistic } \\
\text { Fully or partly outside the } \\
\text { institution } \\
\text { Externally driven (e.g. } \\
\text { professional practice, } \\
\text { community, } \\
\text { business/industry) }\end{array}$ & $\begin{array}{l}\text { Exploratory activity on basis of } \\
\text { professional networks, practice } \\
\text { considerations and development } \\
\text { potential } \\
\text { Accumulation and extension of } \\
\text { range of experience }\end{array}$ & $\begin{array}{l}\text { Creation of options for } \\
\text { future, including } \\
\text { possible exit plan }\end{array}$ \\
\hline Internal & $\begin{array}{l}\text { Script internally driven, based on } \\
\text { e.g. personal and professional } \\
\text { interests, values and strengths } \\
\text { Likely to be oriented towards } \\
\text { service and/or personal com- } \\
\text { fort zone }\end{array}$ & $\begin{array}{l}\text { Pursuit of activity related to personal } \\
\text { values, interests and strengths } \\
\text { Development of relationships, } \\
\text { networks, value-added in relation } \\
\text { to e.g. the student experience, } \\
\text { improved work-life balance }\end{array}$ & $\begin{array}{l}\text { Personal security and } \\
\text { satisfaction } \\
\text { Massaging of } \\
\text { Institutional career } \\
\text { scripts and } \\
\text { progression } \\
\text { pathways } \\
\text { Bespoke career } \\
\text { trajectories }\end{array}$ \\
\hline
\end{tabular}

more transitional Boundaryless script, involving exploration of other options. Contributory factors to the shift towards Institutional and Internal scripts included people becoming more settled, for example, after being promoted or acquiring family responsibilities. Internal scripts were also being used in some instances to build a future case for promotion, an example being the development of employability skills in the curriculum. The shift away from Boundaryless scripts could also have reflected perturbations in the environment between 2017 and early 2020, evidenced by the UK University and College Union (UCU) strike action in the spring and summer of 2018; the requirement for evidence of impact in research in the 2021 Research Excellence Framework; and the gradual introduction of the UK Teaching Excellence and Student Outcomes Framework in England from 2017.

More generally, the fluidity between scripts demonstrated that, in practice, people may hold different scripts simultaneously or at different stages of their career, moving between activities

Table 4 Categorisation of dominant career scripts of individuals after first and second round of interviews

\begin{tabular}{|c|c|c|c|c|c|c|}
\hline \multirow[b]{2}{*}{ Career scripts } & & \multicolumn{5}{|c|}{$\begin{array}{l}\text { Categorisation of dominant career } \\
\text { scripts of individuals after second interview }(2019 / 2020)\end{array}$} \\
\hline & & $\begin{array}{l}\text { Institu- } \\
\text { tional } \\
\text { scripts }\end{array}$ & $\begin{array}{l}\text { Boundaryless } \\
\text { scripts }\end{array}$ & $\begin{array}{l}\text { Internal } \\
\text { scripts }\end{array}$ & $\begin{array}{l}\text { (No } \\
\text { second interview) }\end{array}$ & Totals \\
\hline \multirow{4}{*}{$\begin{array}{l}\text { Categorisation } \\
\text { of dominant career scripts of } \\
\text { individuals after first } \\
\text { interview }(2017 / 2018)\end{array}$} & Institutional & 13 & 1 & 1 & (3) & $15(18)$ \\
\hline & Boundaryless & 4 & 2 & 6 & (2) & $12(14)$ \\
\hline & Internal & 5 & 0 & 7 & (5) & $12(17)$ \\
\hline & Totals & 22 & 3 & 14 & (10) & $39(49)$ \\
\hline
\end{tabular}


for specific purposes and according to circumstances. As a result, individuals expand and contract their activity across both spatial and temporal dimensions, as shown in the following sections. A career becomes a multifaceted process, involving unique patterns of movement as individuals adjust their positioning.

\section{From the zig-zag to the concertina career-negotiating space and time}

Career paths tend to be represented formally by institutions as fixed, linear models that outline routes, markers of achievement and associated timescales. However, individuals may not necessarily be predisposed, or able, to follow a predetermined path. Thus "There's a thing called a career and for some people it defines a sort of logical series of steps. In my case, it describes a sort of zigzagging way through the world" (senior lecturer, applied science, pre1992 university, interview 1). Another person, who was ambitious for promotion, but whose career had been tempered by life events, reflected that they had "meander[ed] through a career..." (reader, applied science, pre-1992 Russell Group university, interview 2); and another, that career-making "becomes a lifestyle decision as much as anything else..." (senior lecturer, engineering, pre-1992 Russell Group university, interview 2).

Influenced by the three career scripts described in Table 3, career paths are therefore likely to be characterised by an expansion and contraction of activity, as well as a stretching and compression of timescales, according to real life circumstances and contexts. This "concertina" effect is driven by choices and micro-decisions that individuals make on an ongoing basis: "...you have these choices to make... you need to weigh up those choices..." (professor, social sciences, post-1992 university, interview 2). In practice, individuals flex activities, with a sense of testing out possibilities in relation to opportunities, setbacks and personal circumstances. The space/time nexus is exemplified in decisions such as to whether to focus on achieving a balanced range of activity at the same time, or to prioritise a specific activity such as a research initiative or setting up a new teaching programme. Thus, one individual said that they would have to "let things go and create the space to allow [me] to do the things that will help [me] to progress..." (educational developer, pre-1992 Russell Group university, interview 2). Space and time are therefore managed as resources that individuals seek to adjust as they endeavour to find an appropriate fit between the requirements of a career and their own unique circumstances: “... you have to play a long game..., where you choose which bits of the puzzle you can concentrate on at any one time..." (reader, creative arts, post-1992 university, interview 2). The narratives therefore illustrate ways in which individuals "build multiple, subjective positions" (Arvaja, 2018) via Internal scripts, as well as calibrating progress against formal institutional criteria.

\section{Negotiating space}

It was evident from the narratives that individuals had a hinterland against which they contextualised and negotiated their careers, with different career scripts dominating at different times and in response to different circumstances. Space was not only disciplinary, but involved other commitments, internal and external to the university, as well as relationships with others. Thus, the following person demonstrated the way in which their career was nested within their immediate geographic locale, and relationships with colleagues, family and research associates: “... the question is in my case more about family and therefore location... family is too important to me to commute... the long-term plan is to stay here... I'll probably hope to be 
senior lecturer, [and in] ten years' time, reader... If things go very well, professor..." (research fellow/lecturer, applied science, pre-1992 university, interview 1). Professionally, they felt that their research had been facilitated and enriched by "...research partners and government agencies that I help in [third world country] ..." (interview 2). This illustrates the way that both strong ties with family and colleagues and weak ties externally (Granovetter, 1973), i.e. spatial relationships, play their part in the development and direction of a career, with a fluid interaction between internal, institutional and external activity.

Other individuals demonstrated Internal scripts that had led them to develop extended disciplinary space around, for instance, the student experience, teaching and learning and professional practice. Thus, a mid-career academic was mixing language teaching with a range of activities, such as developing graduate employability and teaching enhancement, as a platform for moving on. To do this, they had accessed new networks: "it will be changing my career... I've got access to the sort of conversations... the sort of data..." (senior lecturer, languages, pre-1992 university, interview 1). Another described retrospectively how they had been able to push the boundaries in meeting system requirements for progression, using the development of a database as their scholarly contribution and a marker of achievement in a humanities subject: "I was at the cutting edge... and my digital [work] also fed back into my teaching...” (professor, humanities, pre-1992 Russell Group university, interview 1). Others had harnessed professional practice in support of a case for promotion. Thus, the following person had reinforced activity aimed at meeting the university's formal requirements, reported in interview 1, by writing a successful bid for training funds that would play to the institution's impact agenda. This had led to promotion: "[for] senior lecturer, they are looking at course leadership, module development, and that is what I'm making sure I get involved in (interview 1)... There was some new government policy... that meant that there was an opportunity to develop some training... there's been a lot of external influences that have allowed me to develop the courses that I run... I'd certainly be looking to go for a professorship..." (interview 2) (senior lecturer, social sciences, post-1992 university). As a result, they had been able to stretch the space they occupied, utilising their unique set of skills and community experience as credit towards their career advancement.

It was therefore evident that the spatial parameters of a career were being stretched in two ways: firstly to enable a juggling of activities along a career path, often to accommodate what one person referred to as a "patchwork" lifestyle; and secondly through the emergence of new forms of work around disciplinary activity. Individuals were not only interacting with existing structures, but creating new, lateral spaces. These spaces, and the values attached to them, were less likely to be acknowledged in institutional career templates, but rather to emerge from Internal career scripts.

\section{Negotiating time}

The juggling of time was a recurring theme, again in response to Internal career scripts. This could be in the short term, for example, to allow for a specific research, teaching or writing task to take place, or in the longer term, to allow for activities that might carry less credit in Institutional career scripts, for example, in professional practice or the community, or to accommodate family life. In the shorter term, a number of individuals spoke of trying to create dedicated blocks of time, rather than trying to undertake a range of tasks simultaneously: “...when you're writing papers and... research grants... they're done [to] very tight timelines... if you didn't have a block of time to do it, it could make a difference" (professor, applied 
science, pre-1992 Russell Group university, interview 1). In the longer term, if time was not available to gain the required markers of achievement, this could lead to a stretching of the timescale of a career, as exemplified by the following individual. On the one hand, because they had a limited publication and grant record, plus a young family, they spoke of the route to professor as being "a longer road..." (reader, creative arts, post-1992 university, interview 1). On the other hand, they had been opportunistic in accepting vacancies that had occurred for deputising roles in order to gain credit for future promotion. Thus, "there [are] definitely potential conflicts between the way in which the promotional system is seen to work on paper, and then how it seems to pan out within the process itself" (reader, creative arts, post-1992 university, interview 1). Conversely, another interviewee had postponed having a family, deciding to develop their career early on: "I need[ed] to get promoted before I [had] children, so I did lots and lots... of... research. After I had [children], I was part-time..." (senior lecturer, applied social science, post-1992 university, interview 1).

Others described experiencing stops and starts in their career: "...my approach.... was... if it looks like this might be promising, let's have a go at that and..., see if we can then go further..., if that door closes..., we'll do it this way and..., I had challenges in my immediate family with caring responsibilities... So, a lot of... furthering my own development has [been] to take a step forward and then maybe a bit of a gap, and then another..., it's not necessarily that you can even take the immediate opportunity in front of you... people are not necessarily equally placed at all to be able to take those routes, even when they [are presented] to them..." (professor, social sciences, post-1992 university, interview 2). This demonstrates the way in which an individual may negotiate the terrain of a career in the light of opportunities that arise and their personal circumstances, reflecting the lived experience of career-making.

Time itself was also seen as a resource that could be invested or wasted. Thus, one person had calculated that some local roles carried more weight than others: "I did the admissions tutor role for five years in the end. I didn't really want to do it for five years because it's not one that's particularly valued in terms of things like promotion or role, and it's very timeconsuming. Both time-consuming and not valued is not a great combination...” (reader, creative arts, post-1992 university, interview 1). However, while this person saw this role as consuming valuable time, others might well have seen this or similar roles as an investment in terms of the satisfaction or enjoyment they gained from it, reflecting different Internal scripts. Some people spoke of time as being as valuable as money in terms of progressing a career, in particular being released from teaching, management or administrative roles to invest in research, or as in the following case, to achieve better work-life balance: "It's not about the money, it's about having time to do your job..." (professor, psychology, pre-1992 university, interview 2).

Control of time was also a critical issue and, where it could be controlled, a positive aspect of working in higher education: "you can do what you want largely; you can drive your own research agenda..." (senior lecturer, engineering, pre-1992 Russell Group university, interview 2). However, time could disappear, and create strain, if roles overlapped, as in the case of the following person, who had moved from a research fellow post to a lectureship in the two year period between interviews: "I'm trying to do two jobs... because I'm finishing off a backlog for a previous role... [when] you've worked on something which is $80 \%$ done, you're not just going to stop..." (lecturer, applied science, pre-1992 university, interview 2). Another issue that arose around time was that a number of respondents said that in order to be promoted, you had to demonstrate that you had already been working at a higher level, so in that sense it was a retrospective rather than an aspirational process: "The academic promotion structure is very 
strange to a lot of people, because it's based on what you've done, not on what you're going to do in your new job" (professor, applied science, post-1992 university, interview 1). This could lead to a sense of trying to get ahead of oneself in terms of achievements over a certain timescale, in order to fulfil in advance the requirements for the next promotion.

It was evident that people's careers differed in length and pace. Some individuals may enter higher education part way through their working lives. Others may move in and out. Some people make a positive decision to go for promotion early on, and then focus on family life or a specific interest, or vice versa. Although everyone has the same amount of "clock" time, the way they experience this is likely to differ, and the stages of an individual's career may be elongated or compressed in concertina fashion. This finding provides a further gloss on perceptions of the acceleration of academic life and shortening of timescales (Gibbs et al., 2015; Henkel, 2011; Locke, 2017; Peters, 2015; Vostal, 2016), by focusing on ways in which individuals attempt to manage this in relation to the tempo of their careers. There was a sense of taking back control, for instance, by segmenting a career, creating disjuncture in relation to Institutional scripts. Although linear career models tend to assume that individuals will take action to meet certain milestones within certain timescales in order to progress, in practice, they may also decide not to take action or to defer activity, for example, because of a specific interest or professional commitment, opportunities that arise at the wrong time or family circumstances. The shape of a career may therefore stretch or compress over time, in the short and longer term.

\section{Discussion}

The study on which this paper is based extends understandings of contemporary practices of academic career-making by demonstrating that "boundaried" and "boundaryless" approaches to careers, as described in the literature, are not mutually exclusive, and may coexist and/or shift over time, as individuals fashion Internal, subjective career scripts according to their own preferences, choices and opportunities. They do this by modulating and individualising Institutional scripts and by extending the spaces and timescales available to them. Such internally generated scripts enable them to circumnavigate Institutional scripts by drawing on their own resources, including personal strengths and commitments, extended disciplinary interests and professional practice. In many cases, such scripts might be seen as a backup to formal frameworks, offering protection to the individual, for instance, in relation to actual or potential career setbacks, work-life balance or a possible exit plan, therefore offering the possibility of maintaining some equilibrium in what might be uncertain conditions. Thus, while formal Institutional scripts might be seen to offer material security, if they can be achieved, internally generated scripts allow an accommodation to current circumstances, at least for the time being, rather than a necessary prioritisation of career advancement. Furthermore, individuals appeared willing to articulate this Internal script to line managers, rather than feeling obliged to claim that progression up the formal career ladder was their sole motivation at all times and in every circumstance.

This process is framed theoretically by Archer's concept of "morphogenesis". Academic staff might be said to have moved from being what Archer terms "primary agents", that is "members of collectivities who share the same life [or career] chances" (Archer, 2000: 11, authors' italics), positioned involuntarily within given career structures, to what she terms "actors", who "acquire their social identities from the way in which they personify the roles [or 
sequence of roles in career-making] they choose to occupy" (Archer, 2000: 261, authors' italics). They do this through their own interpretation and/or extension of their roles, via Internal scripts, making constant adjustments over space and time, so as to create elasticity within formal career structures. These adjustments are reflected in ongoing micro-shifts by individuals, in particular their willingness to personalise career paths and to articulate their needs and aspirations to line managers. Thus, the interplay between individual and institution becomes multifaceted during the process of career-making. This process is more complex than a dual, structure and agency binary, and in turn may lead to the modification of institutional policy more generally, although in the initial stages this may be implicit rather than explicit.

It was therefore evident that individuals were able to flex formal requirements in order to accommodate activity that was not necessarily recognised in Institutional career scripts. This could occur when such activity was developmental, for example in relation to graduate employability, particularly if an individual had a line manager who adopted a generous interpretation of progression criteria, and was able to argue that such activities played to university interests. The study demonstrates that the potentials of extended academic activity, driven by Internal scripts, may in practice be realised, although not necessarily recognised, by institutions. Therefore the onus is on institutions to recognise and incorporate a broadening range of contributions associated with academic activity, in particular innovative work, and to reform their requirements so that these align with the lived reality of roles and careers in higher education. This is likely to involve negotiating a new psychological and social contract with academic staff to prevent faith in institutional structures declining. However, it is also for individuals to explore spaces where they think that they can add value, and to be persuasive about these.

Although it was evident that many middle managers, such as heads of department, listened to their staff and the latter's articulation of individual strengths, needs and aspirations, there appeared to be a gap, or at least a time lag, between local understandings and, for example, formal recognition, reward and career development policies. This is likely to become particularly pressing post-COVID, for example, in relation to extended activity related to online learning, equity and diversity, public engagement and community outreach. Closing this gap should be a priority, and there is scope to explore the potentials for doing this in future research studies, for example, by out-posting representatives of senior management teams, and/or the professional services staff supporting them, within schools and faculties, either full-time or part-time.

\section{Conclusion}

The concept of the concertina career has been developed to illustrate how academic staff, even when established in their careers, accommodate to local circumstances and develop workarounds by flexing the space and time available to them. Therefore, career-making, as experienced by the individual, is more dynamic and complex than suggested by fixed career models and linear career paths. The articulation of Internal career scripts suggests an easement to the requirements of institutional career templates, offering a more nuanced account than that provided by the "boundaried/boundaryless" dichotomy, and leading to a fluidity in careermaking across formal parameters. These scripts are in turn influenced by the diversification of the academic workforce; by new, multiple arenas of activity associated with academic work; by professional practice; and by personal lifestyle considerations. 
On the one hand, institutional (or system) career templates provide route maps, with promotion/progression criteria and timelines as place markers that assume a unitary direction and a uniform, or at least, predictable, pace of travel. On the other hand, individual approaches to career-making are likely to involve an exploration, interpretation and stretching of spaces along the given route, as individuals not only interact with the structures they encounter, but also discover and create new spaces that they may use for career credit. Timescales may also be adapted or extended in order to accommodate opportunities and personal circumstances, reflecting both opportunism and pragmatism. Thus, in practice, a unilinear career trajectory becomes multidimensional. A career is represented not only by public indicators such as promotion criteria, markers of esteem and impact, but also by private constructions around these. Internal career scripts promote individual accommodations, values and motivations, leading to the concept of the concertina career, in which individuals expand and contract activity, and extend and compress timescales.

Funding This paper draws on a study entitled The future higher education workforce in locally and globally engaged HEIs. The support of the Economic and Social Research Council (UK), the Office for Students (UK) and Research England (UK) (grant reference ES/M010082/1) is gratefully acknowledged, along with support from the Centre for Global Higher Education (CGHE), UCL Institute of Education, London, UK.

Data availability The data upon which this paper draws is deposited with the UK Data Archive.

\section{Declarations}

Conflict of interest The authors declare no competing interests.

Open Access This article is licensed under a Creative Commons Attribution 4.0 International License, which permits use, sharing, adaptation, distribution and reproduction in any medium or format, as long as you give appropriate credit to the original author(s) and the source, provide a link to the Creative Commons licence, and indicate if changes were made. The images or other third party material in this article are included in the article's Creative Commons licence, unless indicated otherwise in a credit line to the material. If material is not included in the article's Creative Commons licence and your intended use is not permitted by statutory regulation or exceeds the permitted use, you will need to obtain permission directly from the copyright holder. To view a copy of this licence, visit http://creativecommons.org/licenses/by/4.0/.

\section{References}

Archer, M. (2000). Being Human: The Problem of Agency. Cambridge University Press.

Archer, L. (2008). The new neoliberal subjects? Younger academics' constructions of professional identity. Journal of Education Policy, 23(3), 265-285.

Arthur, M. B., \& Rousseau, D. M. (Eds.). (1996). The boundaryless career. Oxford University Press.

Arvaja, M. (2018). Tensions and striving for coherence in an academic's professional identity work. Teaching in Higher Education, 23(3), 291-306.

Baruch, Y. (2004). Managing Careers: Theory and Practice. FT Prentice Hall.

Baruch, Y. (2013). Careers in academe: The academic labour market as an eco-system. Career Development International, 18, 196-210.

Coates, H., \& Goedegebuure, L. (2010). The Real Academic Revolution. L. H. Martin Institute.

Dany, F., Louvel, S., \& Valette, A. (2011). Academic careers: the limits of the 'boundaryless approach' and the power of promotion scripts. Human Relations, 64(7), 971-996.

Delanty, G. (2008). Academic identities and institutional change. In R. Barnett \& R. di Napoli (Eds.), Changing Identities in Higher Education: Voicing Perspectives. Routledge. 
Dowd, K. O., \& Kaplan, D. M. (2005). The Career Life of Academics: Boundaried or Boundaryless? Human Relations, 58(6), 699-721.

Duberley, J., Mallon, M., \& Cohen, L. (2006). Exploring career transitions: accounting for structure and agency. Personnel Review, 35(3), 281-296.

Enders, J., \& de Weert, E. (Eds.). (2009). The Changing Face of Academic Life: Analytical and Comparative Perspectives. Palgrave Macmillan.

Galaz-Fontes, J. F., Arimoto, A., Teichler, U., \& Brennan, J. (Eds.). (2016). Biographies and Careers throughout Academic Life. Springer.

Garbe, E., \& Duberley, J. (2019). How careers change: understanding the role of structure and agency in career change. The case of the humanitarian sector. The International Journal of Human Resource Management. https://doi.org/10.1080/09585192.2019.1588345.

Gibbs, P., Ylijoki, O.-H., Guzman-Valenzuela, C., \& Barnett, R. (Eds.). (2015). Universities in the Flux of Time: An Exploration of Time and Temporality in University Life. Routledge.

Glaser, J. \& Laudel, G. (2015). The Three Careers of an Academic. Discussion Paper Nr. 35/2015. Technishe Universitat Berlin.

Gornall, L., Cook, C., Daunton, L., Salisbury, J., \& Thomas, B. (2014). Academic Working Lives: Experience, Practice and Change. Bloomsbury.

Granovetter, M. (1973). The strength of weak ties. American Journal of Sociology, 78(6), 1360-1380.

Henkel, M. (2000). Academic Identities and Policy Change in Higher Education. Jessica Kingsley.

Henkel, M. (2011). New Public Management, Academic Time and Gender Inequality. In R. M. O. Pritchard (Ed.), Neoliberal Developments in Higher Education (pp. 231-253). Peter Lang.

Jones, D., Visser, M., Stokes, P., Ortenblad,, A., Deem, R., Rodgers, P. and Tarba, S. (2020). "The performative university: 'Targets', 'Terror'“and 'Taking Back Freedom' in academia”. Management Learning 1-15.

Kaulisch, M., \& Enders, J. (2005). Careers in overlapping institutional contexts: The case of academe. Career Development International, 10(2), 130-144.

Kwiek, M. (2019). Changing European Academics: A Comparative Study of Social Stratification, Work Patterns and Research Productivity. Routledge.

Kwiek, M., \& Antonowicz, D. (2015). The Changing Paths in Academic Careers in European Universities: Minor Steps and Major Milestones. In T. Fumasoli, G. Goastellec, \& B. Kehm (Eds.), Academic Work and Careers in Europe: Trends, Challenges, Perspectives (pp. 41-68). Springer.

League of European Research Universities (2014). "Tenure and Tenure Track at LERU Universities: Models for attractive research careers in Europe". https:/www.leru.org/files/Tenure-and-Tenure-Track-at-LERUUniversities-Full-paper.pdf.

Leisyte, L., \& Hosch-Dayican, B. (2016). Boundary crossing and maintenance among UK and Dutch bioscientists: towards hybrid identities of academic entrepreneurs. In L. Leisyte \& U. Wilkesmann (Eds.), Organising academic work in higher education: teaching, learning and identities (pp. 223-242). Routledge.

Locke, W. (2017). The Changing Dynamics of UK Higher Education Institutions in an Increasingly Marketised Environment: Academic Work and Rankings, $\mathrm{PhD}$ Thesis, University College London: https://discovery.ucl. ac.uk/id/eprint/10038660/

Locke, W., Whitchurch, C., Smith, H., \& Mazenod, A. (2016). Shifting Landscapes: meeting the staff development needs of the changing academic workforce. Higher Education Academy.

Machado-Taylor, M., Soares, V. M., \& Teichler, U. (Eds.). (2017). Challenges and Options: The Academic Profession in Europe. Springer.

Mainiero, L., \& Sullivan, S. (2006). The Opt-out Revolt: Why People are Leaving Companies to Create Kaleidoscope Careers. Davis-Black.

Marini, G. (2019). A PhD in social sciences and humanities: impacts and mobility to get better salaries in an international comparison. Studies in Higher Education, 44(8), 1332-1343.

McAlpine, L. (2010). Meaning and purpose in academic work: implications for early career academics. SRHE Conference 14-16 December 2010, Newport.

McAlpine, L., \& Amundsen, C. (2018). Identity-Trajectories of Early Career Researchers: Unpacking the PostPhD Experience. Palgrave Macmillan.

Musselin, C. (2013). Redefinition of the relationships between the academics and the universities. Higher Education, 65, 25-37.

Ortlieb, R., \& Weiss, S. (2018). What makes academic careers less insecure? The role of individual-level antecedents. Higher Education, 76(4), 571-587.

Peters, M. A. (2015). The University in the Epoch of Digital Reason: Fast Knowledge in the Circuits of Cybernetic Capitalism. In P. Gibbs, O.-H. Ylijoki, C. Guzman-Valenzuela, \& R. Barnett (Eds.), Universities in the Flux of Time: An Exploration of Time and Temporality in University Life (pp. 9-31). Routledge. 
Pietilä, M. (2017). Incentivising academics' experiences and expectations of the tenure track in Finland. Studies in Higher Education, 44(6), 932-945.

Pietilä, M., \& Pinheiro, R. (2020). Reaching for different ends through tenure track - institutional logics in university career systems. Higher Education. https://doi.org/10.1007/s10734-020-00606-2.

Pifer, M. J., \& Baker, V. L. (2016). Professional, personal, and relational: Exploring the salience of identity in academic careers. Identity: An International Journal of Theory and Research, 16(3), 190-205.

Rosewell, K., \& Ashwin, P. (2019). Academics' perceptions of what it means to be an academic. Studies in Higher Education, 44(12), 2374-2384.

Siekkinen, T., Pekkola, E., \& Carvalho, T. (2019). Change and continuity in the academic profession: Finnish universities as living labs. Higher Education, 79(3), 533-551.

Strike, A., \& Taylor, J. (2009). The career perceptions of academic staff and human resource discourses in English higher education. Higher Education Quarterly, 63(2), 177-195.

Sullivan, S. E., \& Baruch, Y. (2009). Advances in career theory and research: A critical review and agenda for future exploration. Journal of Management, 35, 1542-1571.

Super, D. E. (1992). Toward a comprehensive theory of career development. In D. H. Montross \& C. J. Shinkman (Eds.), Career development: Theory and practice (pp. 35-64). Charles C Thomas.

Vostal, F. (2016). Accelerating Academia: The Changing Structure of Academic Time. Palgrave Macmillan.

Watermeyer, R., \& Tomlinson, M. (2021). Competitive accountability and the dispossession of academic identity: Haunted by an impact phantom. Educational Philosophy and Theory. https://doi.org/10.1080/ 00131857.2021 .1880388 .

Whitchurch, C. (2018). From a diversifying workforce to the rise of the itinerant academic. Higher Education, 77(4), 679-694.

Whitchurch, C., Locke, W., \& Marini, G. (2019). A Delicate Balance: Optimising Individual Aspirations and Institutional Missions in Higher Education. Centre for Global Higher Education (CGHE) Project 3.2 Working Paper 45.

Ylijoki, O.-H. (2013). Boundary-work between work and life in the high-speed university. Studies in Higher Education, 38(2), 242-255.

Ylijoki, O-H \& Henriksson, L. (2017). Tribal proletarian and entrepreneurial career stories: junior academics as a case in point. Studies in Higher Education 42(7): 1292-1308.

Ylijoki, O.-H., \& Ursin, J. (2013). The construction of academic identity in the changes of Finnish Higher Education. Studies in Higher Education, 38(8), 1135-1149.

Yudkevich, M., Altbach, P. G., \& Rumbley, L. (Eds.). (2015). Young Faculty in the Twenty-First Century. International Perspectives. State University of New York Press.

Zacher, H., Rudolph, C. W., Todorovic, T., \& Ammann, D. (2019). Academic career development: A review and research agenda. Journal of Vocational Behaviour, 110B, 357-373.

Publisher's note Springer Nature remains neutral with regard to jurisdictional claims in published maps and institutional affiliations.

\title{
Affiliations
}

\section{Celia Whitchurch ${ }^{1} \cdot$ William Locke ${ }^{2} \cdot$ Giulio Marini $^{3}$}

\author{
William Locke \\ william.locke@unimelb.edu.au \\ Giulio Marini \\ g.marini@ucl.ac.uk
}

1 Centre for Global Higher Education, UCL Institute of Education, 20 Bedford Way, London WC1E 0AL, UK

2 Centre for the Study of Higher Education, University of Melbourne, Elisabeth Murdoch Building, Parkville, Victoria 3010, Australia

3 Quantitative Social Science, University College London, 27-28 Woburn Square, London WC1E 0AA, UK 